УДК 614.253.4:616.314

DOI: https://doi.org/10.33989/2075-146x.2020.25.223347

\title{
КСЕНІЯ ЮДІНА
}

ORCID: 0000-0003-3773-8474

Українська медична стоматологічна академія, м. Полтава

\section{ВИЗНАЧЕННЯ БАЗОВИХ КОМПЕТЕНТНОСТЕЙ СТУДЕНТІВ-СТОМАТОЛОГІВ}

\begin{abstract}
У статті проаналізовано, обгрунтовано та визначено основні базові компетентності студентів стоматологів та розглянуто процес їхнього розвитку в ЗВО України. Зроблено висновок, що поняття "компетентність" досі не має чіткого розуміння в міжнародній науковій спільноті. Дослідники підходять до компетентності з різних точок зору: готовність до діяльності; сукупність ключових, базових умінь; здатність діяти на основі власних знань та досвіду; коло питань, у яких людина добре обізнана. Автор розглядає компетентність у контексті освоєння того чи іншого виду діяльності, виступаючи у ролі готовності і мотивації до розв'язання проблем i реалізовуватися у досягненні успіху.
\end{abstract}

Ключові слова: базові компетентності, ключові компетентності, студенти, стоматологи, 3ВО України, компетентність, компетенції, навчальний процес, компетентнісний підхід

Постановка проблеми. За сучасними поняттями, професійна компетентність - всебічне уявлення, що припускає собою взаємозв'язок ключової, базової та спеціальної компетенцій. Ключові компетентності потрібні для будь-якої високопрофесійної діяльності, вони виявляються в можливості вирішувати професійні цілі на основі задіяння інформації, комунікації, соціально-правових основ взаємин особистості в цивільному співтоваристві. Базові компетентності висвічують специфічність відповідної високопрофесійної діяльності (педагогічної, медичної, інженерної та т. д.). Спеціальні компетентності висвічують особливість певної галузі професійної діяльності. Ключові, базові та спеціальні компетентності професіонала реалізуються при вирішенні професійних цілей в різних контекстах, із задіянням відповідного освітнього простору. Отже, для підготовки високопрофесійних спеціалістів вкрай важливо усвідомлювати значущість розвитку базових компетентностей у студентів, майбутніх стоматологів, та втілювати принципи компетентнісного підходу під час їх підготовки у ВНЗ України (Юдіна, 2018).

Зв'язок із важливими науковими та практичними завданнями. В умовах підписаної представниками 3 більш ніж 100 університетів 316 країн, Болонської декларації та моделі,розробленої і прийнятої у рамках програми TUNING (“Налаштування освітніх структур”), виділено ключові (базові) компетенції/ компетентності. Дана модель має кілька груп компетенцій, що об’єднані у два блоки: загальні та спеціальні (професійні) компетенції.

Загальні компетенції відповідають ключовим компетенціям і включають:

1. Інструментальні компетенції: лінгвістичні та технологічні вміння, комунікативні компетенції, когнітивні та методологічні здібності.

2. Міжособистісні компетенції: соціальні навички, уміння працювати в відповідних групах, соціальна співпраця і взаємодія, прийняття соціальних та етичних зобов'язань; індивідуальні здібності, пов'язані 3 критичним осмисленням і здатністю до самокритики, умінням виражати почуття і стосунки.

3. Системні компетенції: здатність робити зміни з метою вдосконалення певних систем і конструювати нові, ставлення і знання, поєднання розуміння для адекватного сприйняття співвідношення частин цілого і оцінювання місця кожного з компонентів у системі (Юдіна, 2018; Онопрієнко, 2007).

Аналіз останніх досліджень і публікацій із проблеми. Найвідоміші праці, присвячені питанням компетентнісного підходу, Б. Ананьєва, В. Байденко, Г. Беліцького, Л. Берестова, І. Беха, Н. Бібік, В. Болотного, Л. Ващенко, В. Вербицького, Л. Виготського, І. Гавриш, Н. Грішанова, І. Гудзик, Т. Гуляєвої, Р. Девлетова, Д. Заводчикова, Г. Зайчука, Е. Зеєра, І. Зимньої, В. Кременя, Т. Кристопчук, Н. Кузнєцової, Н. Кузьміної, В. Куніциної, А. Леонтьєва, О. Локшиної, В. Лугового, А. Маркової, Н. Мурованої, О. Овчарук, О. Пометун, М. Пустового, Дж. Равена, І. Родигіної, С. Рубінштейна, О. Савченко, Г.Селевка, В. Серікова, М. Сосніна, Н. Табачук, Ю. Татура, С. Трішиної, Р.Уайта, М. Філатова, Т.Філя, Н.Хомського, О.Хохліної, А. Хуторського, Ю. Швалба та ін.

Визначення «компетенції» та «компетентності» дають такі міжнародні організації як ЮНЕСКО, Освітня комісія Ради Європи, Міжнародний департамент стандартів, експерти програми «Визначення та відбір компетентностей: теоретичні й концептуальні засади», «DeSeCo» тощо. Відповідно до завдань Ради Свропи основні компетентності розглядали - І. Гушлевська, А. Дахін, І. Срмаков, О. Карпенко, С. Клепко, та ін. (Овчарук, 2004; Хуторской, 2003).

Розкриття компетентностей майбутніх фахівців галузі здоров'я людини наявно у дослідженнях: Т. Бондаренко, Д. Вороніна, І. Іваній, Я. Кульбашної, Н. Левінець, С. Новописьменного, О. Онопрієнка та ін.

Визначенням та розкриттям базових компетентностей займались такі дослідники: Н. Андрущенко, О. Бєлорибкіна, І. Борець, А. Волкова, В. Вишпольська, А. Гордійчук, В. Гришко, Ю. Дишлова, В. Єгорова, С. Кравець, Н. Кузнецова, А. Лановенко, О. Ліскович, С. Новописьменний, О. Онопрієнко, С. Перова, В. Петрук, О. Савченко, В. Уманець та ін. 
Виділення невирішених частин проблеми. Аналіз наукових досліджень та публікацій засвідчив, що в наукових джерелах міститься недостатня кількість наукових розробок щодо визначення та вивчення базових компетентностей студентів-стоматологів та їх розвиток у ВНЗ України.

Особливу увагу слід приділити визначенню певної структури компетентностей. Компетентності є комплексами певних знань, умінь та відповідних ставлень, що відповідають різним видам діяльності, які набуваються у навчанні і дозволяють особистості усвідомлювати, або розуміти та давати оцінку в різних контекстах проблеми. В досвіді певних країн, які впроваджують дану концепцію до змісту освіти, можна спостерігати тенденції розробки певної ієрархії компетентностей на різних рівнях даного змісту. А саме:

1. Надпредметні компетентності (“транспредметні” та “міжпредметні”) - базові які спрямовані на ефективне життя у соціумі та соціальну взаємодію.

2. Загальнопредметні компетентності - їх набуває здобувач освіти упродовж вивчення того чи іншого освітнього компоненту.

3. Спеціальнопредметні - ті, що їх набуває здобувач освіти при вивченні певного освітнього компоненту впродовж певного навчального року або відповідного ступеня навчання (Зимняя, 2003; Селевко, 2004).

Мета статті- визначення базових компетентностей студентів-стоматологів та їх розвиток у ЗВО України.

Виклад основного матеріалу дослідження з повним обгрунтуванням отриманих результатів.

Базові компетентності студентів-стоматологів - це структурно класифіковані комплекси здатностей майбутніх стоматологів застосовувати знання, уміння і навички якості особистості, які служать певною стандартизованою основою для відображення специфіки й забезпечення якості виконання професійних завдань стоматологів i орієнтують на освіту протягом життя (Локшина, 2007; Пометун, 2004).

Відповідно до класифікації базових компетентностей, запропонованих Н. Бібік, О. Благій, М. Василенко, Л. Ващенко, А. Вовканич, М. Гриньовою, М. Дутчак, О. Ждановою, О.Локшиною, О. Марченко, С. Новописьменним, О. Овчарук, С. Страшком, Л. Сущенко та ін., виділяють: дослідницько-аналітичні, технологічні, організаційні, управлінські, інформаційно-комунікаційні та здоров'язбережувальні компетентності.

Згідно з результатами дослідження фундаментальних (базових) компетентностей особистості XXI ст., які у своєму звіті за 2017 рік подає відома у професійних колах Association for Talent Development (ATD, USA), можна визначити наступні базові компетентності особистості як:

- бізнес навички (демонструє розуміння бізнесу, важливості забезпечення його результатів і наслідків);

- глобальне мислення (ефективна співпраця без: кордонів, культурного розмаїття, вікових відмінностей);

- галузеві знання (підтримка знань із відповідних галузей і сегментів);

- міжособистісна взаємодія (взаємодія з іншими людьми для налагодження впливу і довіри);

- особисті навички (навички, що демонструють адаптивність і бажання постійного навчання);

- технологічна обізнаність (навички, що демонструють обізнаність і знання існуючих та перспективних технологій) (Association for Talent Development, 2017).

Враховуючи недостатню кількість наукових джерел щодо визначення базових компетентностей студентівстоматологів та спираючись на нормативну базу щодо процесу навчання студентів-стоматологів у медичних 3ВО України, зокрема на Галузевий стандарт вищої освіти (Освітньо-кваліфікаційна характеристика спеціаліста за спеціальністю - 7.110106 стоматологія, напряму підготовки - 1101 медицина, та Освітньо-професійна програма підготовки спеціаліста за спеціальністю - 7.110106 стоматологія, напряму підготовки - 1101 медицина), пропонується наступний перелік базових компетентностей студентів-стоматологів:

Гуманітарна і соціально-економічна підготовка (освітня орієнтація):

- здатність аналізувати передконфліктні і конфліктні ситуації та сприяти їх розв'язанню;

- здатність визначати значення політичної активності медиків як соціально-політичної групи;

- здатність визначати індивідуально-психологічні відмінності особистості за їхніми проявами у діяльності та спілкуванні;

- здатність визначати місце медиків як соціальної групи у соціальній структурі суспільства;

- $\quad$ здатність визначати роль соціальних та соціально-психологічних чинників в розповсюдженні хвороб;

- здатність використовувати принципи моралі та враховувати національні та релігійні особливості;

- здатність використовувати різні мовні засоби відповідно до сфери і мети висловлювання;

- здатність використовувати у професіональній та науковій діяльності категорії та закони діалектики;

- здатність використовувати фахову нормативну лексику;

- здатність виявляти особливості вираження емоцій та розкривати їх зв'язок з іншими психічними процесами;

- здатність демонструвати вміння спілкуватися іноземною мовою в усній та письмовій формах;

- $\quad$ здатність демонструвати володіння загально-науковими та конкретно-науковими методами пізнання та діяльності;

- здатність демонструвати володіння основами політичної культури особистості;

- здатність демонструвати розуміння нормативно-правового регулювання взаємовідносин лікар-хворий;

- здатність демонструвати розуміння принципів фізичної культури;

- здатність диференціювати біологічні, антропологічні, психологічні, соціальні і гносеологічні витоки релігії;

- здатність застосовувати моральні, етичні і фахові норми в професійній і життєдіяльності;

- здатність інтерпретувати зміст медичної літератури іноземною мовою;

- здатність інтерпретувати сутність основ віровчень та культів світових релігій, які впливають на фізичний і психологічний стан людини;

- здатність користуватися критеріями істини при постановці діагнозу; 
- здатність обгрунтовувати значення психологічних та педагогічних знань для майбутньої професійної діяльності;

- здатність опрацьовувати наукові тексти, оформляти та складати ділові документи;

- здатність підтримувати, розвивати і удосконалювати функціональний стан свого організму;

- здатність трактувати основи натуралістично-соціологічних теорій і їх негативні наслідки для виконання професійних функцій;

- здатність представляти суть і структуру нормативно-правового регулювання державою, галуззю та закладами охорони здоров'я;

- здатність розраховувати основні показники господарської діяльності закладів охорони здоров'я;

- здатність складати наукові доповіді і реферати, вести дискусії з актуальних питань історії, зовнішньої і внутрішньої політики української держави;

- здатність трактувати закономірності пізнавально-практичної діяльності людини у професійній роботі лікаря.

Гуманітарна і соціально-економічна підготовка (професійна орієнтація):

- здатність визначати психічний стан та рівень соціально-психологічної адаптації хворих за допомогою методів психологічного дослідження;

- здатність визначати психосоматичні і соматопсихічні взаємовпливи у хворих;

- здатність використовувати греко-латинські медичні терміни в практичній діяльності фахівця;

- здатність використовувати засоби психогігієни, психопрофілактики та основні методи психотерапії у медичній практиці;

- здатність демонструвати вміння спілкуватися з колегами, хворими та їх родичами з урахуванням їх психологічних особливостей, сприяти створенню здорового психологічного клімату в медичному середовищі;

- здатність демонструвати володіння моральною культурою лікаря, етикою взаємовідносин лікар-пацієнт;

- здатність демонструвати володіння принципами медичної деонтології, запобігати виникненню ятрогеній і корегувати наслідки ятрогенних впливів;

- здатність інтерпретувати розвиток медицини в історичній ретроспективі;

- здатність трактувати основні моделі та категорії біомедичної етики;

- здатність трактувати основні історико-медичні події.

Природничо-наукова підготовка:

- здатність визначати вплив соціальних умов та праці на розвиток і будову організму людини;

- здатність визначати можливості застосування інформаційних технологій та ЕОМ в медицині;

- здатність використовувати методи обробки медичної інформації;

- $\quad$ здатність демонструвати базові навички роботи з ПК та пошуку медичної інформації з використанням інформаційних технологій;

- $\quad$ здатність демонструвати володіння морально-етичними принципами ставлення до живої людини та ії тіла як об'єкту анатомічного та клінічного дослідження;

- $\quad$ здатність пояснювати принципи формалізації і алгоритмізації медичних задач, принципи моделювання в біології та медицині;

- здатність передбачати взаємозалежність і єдність структур і функцій органів людини, їх мінливість під впливом екологічних факторів (Галузевий стандарт вищої освіти).

Отже, визначення базових компетентностей у студентів-стоматологів засвідчують розвиток специфічної, відповідної, високопрофесійної діяльності майбутніх спеціалістів. Ключові, базові та спеціальні компетентності професіонала-стоматолога реалізуються при вирішенні професійних цілей в різних контекстах, із застосуванням відповідного освітнього простору. Для підготовки високопрофесійних спеціалістів вкрай важливо усвідомлювати значущість розвитку та формування базових компетентностей у студентів, майбутніх стоматологів, та втілювати принципи компетентнісного підходу під час їх підготовки у ВНЗ України.

Висновки 3 дослідження і перспективи подальших розвідок із напряму. Аналіз наведених вище визначень дає змогу стверджувати, що поняття “компетентність", ще не має чіткого розуміння в міжнародній науковій спільноті. Дослідники підходять до компетентності з різних точок зору: готовність до діяльності; сукупність ключових, базових умінь; здатність діяти на основі власних знань та досвіду; коло питань, у яких людина добре обізнана. На нашу думку - компетентність, це не просто сума знань, умінь та навичок, вона може формуватися у процесі освоєння того чи іншого виду діяльності, виступаючи у ролі готовності і мотивації до розв'язання проблем і реалізовуватися у досягненні успіху. Багато авторів даючи визначення поняття “компетентність” не завжди розмежовують базові (ключові) компетентності та професійні, таким чином не поділяючи соціальне життя особистості та іiі трудову діяльність.

\section{Список використаних джерел}

Галузевий стандарт вищої освіти. Освітньо-професійна програма підготовки спеціаліста за спеціальністю. Взято 3 https://testcentr.org.ua/standards/7.110101\%20medicine\%20(tp).pdf

Зимняя, И. А. (2003). Ключевые компетенции - новая парадигма результата образования. Высшее образование сегодня, 5 , $34-42$.

Коковська, О. В., Міщенко, І. В., Павленко, Г. П., Юдіна, К. Є. (2018). Професійна компетентність науково-педагогічного 
ISSN: Print 2075 - 146X, Online 2616-6623. Витоки педагогічної майстерності. 2020. Випуск 25

працівника як важлива складова якості вищої медичної освіти. В кн. Актуальні питання контролю якості освіти

у вищих медичних навчальних закладах: матеріали наук.-практ. конф. 3 міжнар. участю (С. 125-127). Полтава.

Локшина, О. (2007). Розвиток компетентнісного підходу в освіті Європейського Союзу. Шлях освіти, 1, 16-21.

Овчарук, О. В. (Ред.). (2004). Компетентнісний підхід у сучасній освіті: світовий досвід та украӥнські перспективи: Бібліотека з освітньої політики. Київ: К.І.С.

Овчарук, О.В. (2004). Розвиток компетентнісного підходу: стратегічні орієнтири міжнародної спільноти. В кн.

О. В. Овчарук (Ред.), Компетентнісний підхід у сучасній освіті: світовий досвід та украйнські перспективи (С. 6 -

15). Київ: К.І.С.

Онопрієнко, О. (2007). Концептуальні засади компетентнісного підходу в сучасній освіті. Шлях освіти, 4, 32-37.

Пометун, О. І. (2004). Теорія та практика послідовної реалізації компетентнісного підходу в досвіді зарубіжних країн. В кн. О. В. Овчарук (Ред.), Компетентнісний підхід у сучасній освіті: світовий досвід та украйнські перспективи (С. 15-25). Київ: К.І.С.

Селевко, Г. (2004). Компетентности и их классификация. Народное образование, 4, 138-143.

Хуторской, А. В. (2003). Ключевые компетенции как компонент личностноориентированной парадигмы образования. Народное образование, 2, 58-64.

Юдіна, К. Є., Міщенко, І. В., Жукова, М. Ю. [та ін.]. (2018). Формування професійних компетенцій студентів стоматологічного факультету вищих медичних навчальних закладів як компонент якості освіти. В кн. Актуальнi питання контролю якості освіти у вищих медичних навчальних закладах: матеріали наук.-практ. конф. 3 міжнар. участю (С. 258-259). Полтава.

Association for Talent Development. Retrieved from https://goo.gl/cjRDUy.

\section{References}

Association for Talent Development. Retrieved from https://goo.gl/cjRDUy.

Haluzevyi standart vyshchoi osvity [Industry standard of higher education]. Osvitno-profesiina prohrama pidhotovky spetsialista za spetsialnistiu. Retrieved from https://testcentr.org.ua/standards/7.110101\%20medicine\%20(tp).pdf [in Ukrainian].

Khutorskoi, A. V. (2003). Kliuchevye kompetentcii kak komponent lichnostnoorientirovannoi paradigmy obrazovaniia [Key competencies as a component of a personality-oriented education paradigm]. Narodnoe obrazovanie [Public education], 2, 58-64 [in Russian].

Kokovska, O. V., Mishchenko, I. V., Pavlenko, H. P., \& Yudina, K. Ye. (2018). Profesiina kompetentnist naukovo-pedahohichnoho pratsivnyka yak vazhlyva skladova yakosti vyshchoi medychnoi osvity [Professional competence of a research and pedagogical worker as an important component of the quality of higher medical education]. In Aktualni pytannia kontroliu yakosti osvity $u$ vyshchykh medychnykh navchalnykh zakladakh [Current issues of quality control of education in higher medical educational institutions]: materialy nauk.-prakt. konf. z mizhnar. uchastiu (pp. 125-127). Poltava [in Ukrainian].

Lokshyna, O. (2007). Rozvytok kompetentnisnoho pidkhodu v osviti Yevropeiskoho Soiuzu [Development of the competence approach in education of the European Union]. Shliakh osvity [The path of education], 1, 16-21 [in Ukrainian].

Ovcharuk, O. V. (Ed.). (2004). Kompetentnisnyi pidkhid u suchasnii osviti: svitovyi dosvid ta ukrainski perspektyvy [Competence approach in modern education: world experience and Ukrainian perspectives]: Biblioteka z osvitnoi polityky. Kyiv: K.I.S. [in Ukrainian].

Ovcharuk, O. V. (2004). Rozvytok kompetentnisnoho pidkhodu: stratehichni oriientyry mizhnarodnoi spilnoty [Development of a competency approach: strategic guidelines of the international community]. In O. V. Ovcharuk (Ed.), Kompetentnisnyi pidkhid u suchasnii osviti: svitovyi dosvid ta ukrainski perspektyvy [Competence approach in modern education: world experience and Ukrainian perspectives] (pp. 6-15). Kyiv: K.I.S. [in Ukrainian].

Onopriienko, O. (2007). Kontseptualni zasady kompetentnisnoho pidkhodu v suchasnii osviti [Conceptual bases of the competence approach in modern education]. Shliakh osvity [The path of education], 4, 32-37 [in Ukrainian]. 
ISSN: Print 2075 - 146X, Online 2616-6623. Витоки педагогічної майстерності. 2020. Випуск 25

Pometun, O. I. (2004). Teoriia ta praktyka poslidovnoi realizatsii kompetentnisnoho pidkhodu v dosvidi zarubizhnykh krain [Theory and practice of consistent implementation of the competence approach in the experience of foreign countries]. In O. V. Ovcharuk (Ed.), Kompetentnisnyi pidkhid u suchasnii osviti: svitovyi dosvid ta ukrainski perspektyvy [Competence approach in modern education: world experience and Ukrainian perspectives] (pp. 15-25). Kyiv: K.I.S. [in Ukrainian].

Selevko, G. (2004). Kompetentnosti i ikh klassifikatciia [Competencies and their classification]. Narodnoe obrazovanie [Public education], 4, 138-143 [in Russian].

Yudina, K. Ye., Mishchenko, I. V., \& Zhukova, M. Yu. [et al]. (2018). Formuvannia profesiinykh kompetentsii studentiv stomatolohichnoho fakultetu vyshchykh medychnykh navchalnykh zakladiv yak komponent yakosti osvity [Formation of professional competencies of students of the dental faculty of higher medical educational institutions as a component of the quality of education]. In Aktualni pytannia kontroliu yakosti osvity u vyshchykh medychnykh navchalnykh zakladakh [Current issues of quality control of education in higher medical educational institutions]: materialy nauk.-prakt. konf. z mizhnar. uchastiu (pp. 258-259). Poltava [in Ukrainian].

Zimniaia, I. A. (2003). Kliuchevye kompetentcii - novaia paradigma rezultata obrazovaniia [Key competencies - a new paradigm of educational outcomes]. Vysshee obrazovanie segodnia [Higher education today], 5, 34-42 [in Russian].

\section{YUDINA K.}

Ukrainian Medical Dental Academy, Poltava,Ukraine

\section{DETERMINING THE BASIC COMPETENCIES OF DENTAL STUDENTS}

The article analyzes the state of definition and separation of basic competencies of dental students in the context of their training in medical universities of Ukraine. The main basic competencies of dental students are determined. The importance of a systematic approach to determining the basic competencies of dental students is substantiated. An analysis of the above definitions suggests that the concept of "competence" does not yet have a clear understanding in the international scientific community. Researchers approach competence from different points of view: readiness for activity; a set of key, basic skills; ability to act on the basis of own knowledge and experience; a range of issues in which the person is well aware. In our opinion, competence is not just a sum of knowledge, skills and abilities, it can be formed in the process of mastering one or another type of activity, acting as a readiness and motivation to solve problems and be implemented in achieving success. Many authors, defining the concept of "competence" do not always distinguish between basic (key) competencies and professional, thus not dividing the social life of the individual and his work. Thus, the definition of basic competencies in dental students testify to the development of specific, relevant, highly professional activities of future professionals. The key, basic and special competencies of a professional dentist are realized in solving professional goals in different contexts, using the appropriate educational space.

Key words: basic competencies, key competencies, students, dentists, Ukrainian universities, competence, competencies, educational process, competency approach

Стаття надійшла до редакції 06.08.2020 р. 